\title{
The Uncertainty of the Macroeconomic Impact of the Choice of Macro Economic Policy in China
}

\author{
Limei Cui \\ Qujing normal college, yunnan qujing 655001
}

Keywords: Debt crisis; National economy; Macro policy

\begin{abstract}
As Europe's debt crisis has intensified the trend of world economic development, the uncertain factors in the global economic increase, the development of today, our national economy has been seriously affected, all kinds of inflation crisis deeply, boosting the national economy three carriages is stagnant, the economy of our country is faced with hitherto unknown risks, how to implement the intense discussion of macroeconomic policy is a hitherto unknown high, how to promote the smooth development of China's national economy is a pressing matter of the moment.

In the economic globalization is more and more popular today, the economy of each country are highly operation mode, development speed has hitherto unknown trend, economic globalization is very conducive to China's economic exchanges, promote China's national economy and the rapid development of the world economy, but at the same time, economic globalization has its its inevitable shortcomings, compared with other flaws, one of the most influential is any economy problems such as the European debt crisis, it will lead to a tremendous economic catastrophe in China, as the world economy in second, the blow is hitherto unknown.
\end{abstract}

On the current form of analysis, the reasons for China's national economic uncertainty:

\section{From the External Conditions Down to See}

European Sovereign Debt Crisis. The European economy has been continued to hit, although the European Union and the International Monetary Fund Committee to do the best possible introduction of policies to boost the economic recovery in Europe, but because the individual debt is very huge, is still facing the risk of retrogression. China as the EU's second largest cooperation, by the European debt crisis volatility is very strong, for the import and export business in Europe a large part of the hardest hit, many EU countries adopt tariff barriers to protect the domestic policy, the development of industrial enterprises, resulting in China's export business suffered a heavy blow.

Increased Mobility. Now the dollar prices continue to decline, of course, the euro zone and Japan will continue to follow, global liquidity will continue to present a state of heightened, which impact on China will be further, from coastal areas to inland development will undoubtedly. By the number of Sino US debt transactions, the continued decline in the dollar is very detrimental to the situation of China's foreign exchange reserves. Of course, Japan, as a neighbor of China, also as an economic power, the trade between the two countries is very close. And with the increase in liquidity, the downturn in the economic development of the situation will certainly affect more emerging countries, including the BRIC countries, etc.. The impact of this liquidity on the formation of a vicious circle of China's national economy.

\section{From the Inner Conditions Down to See}

Due to the development of the reform and opening up, China's national economy has been hitherto unknown high-speed development, but China's overall economic growth rate overall is showing abnormal development of the situation in the early stage of development, the growth rate is too fast, dangerous now increase rate of China's national economy is still in the international standard the value, but the value with respect to our country present a downturn, China's economic growth has come to a head, this is a problem worth pondering.

Affected by the international macroeconomic environment, China's export situation is not optimistic, the export of our country is an important part of the national economy, but with the main 
exports in the economy are affected by the economic globalization in the downturn, coupled with China's economy trend of expansion, resulting in higher costs, loss of price advantage. Aggravate the economic uncertainty of our country.

The domestic inflation situation is serious to the inflation, among them the most serious is the crude oil and the metal, these two items regarding our country's industry influence is very huge. Together with the small commodity prices also showed a slight increase, can not be stimulated to the level of national consumption. Food consumption index is also showing an upward trend.

In the face of many problems in the domestic and foreign macroeconomic, to our country a very difficult decision problem, in the end how should implement macroeconomic policies to stimulate domestic demand, stimulate consumption, other national economic recovery, this is a very difficult decision, the author only from their own point of view on their own views, and hope study on all relevant aspects of the experts and scholars of the students. From two aspects of fiscal policy and monetary policy:

\section{A Positive Fiscal Policy to Promote Economic Growth}

Stimulate consumer demand to increase the income of residents, through macro-control, as much as possible to reduce the inflation rate, the development of the third industry, to promote the upgrading of consumption structure.

Deepen the reform of the tax system to actively adopt tax cuts, tax rebates, preferential policies to reduce the burden on enterprises. Policy support for the necessities of the residents. Actively promote the reform of the camp to increase the pace of reform. Stimulating residents' consumption through reform of tax system.

In the process of urbanization and agricultural policies complement each other through the construction of accelerating the process of urbanization, more basic livelihood project started, stimulating domestic demand, utilization of surplus labor. Agriculture as the basic position of China's economy, we should always do the agricultural policy, giving farmers more protection policy, to keep the attention on the issues, make the construction of livelihood projects.

\section{Prudent Monetary Policy to Fine Tune Economic Development}

Financial system reform must push forward the reform of interest rate, and the RMB exchange rate to pay attention to the benchmark interest rate, improve China's financial system, deepening of the joint-stock reform of state-owned banks, pay attention to the balance of the state budget, pay attention to the impact of macroeconomic financial system reform on gold, focusing on promoting rural financial the reform of the system of rural finance of our country, as a weak link, but at the same time, the rural finance of our country is a huge potential market. We must pay close attention to the reform of the financial system, and a good financial system is the basic guarantee for the steady development of China's national economy.

With good credit relationship between the adjustment of economic structure to stimulate domestic demand, stimulate consumption through, promote the upgrading of industrial structure, to give full credit to high-tech industries and emerging technology industries to support efforts to achieve the development of livelihood projects to attract credit funds to the people's livelihood project. To do a good job in public. Credit funds must be applied to the actual problem above, for the traditional old industry, through the credit fund to do a good job restructuring, do not understand the reform of the industrial structure of the group to give timely elimination mechanism.

The whole stable 3 to prevent the financial crisis financial risk in the financial system is the lifeblood of our national economy, the economy of other countries of the financial crisis on China has caused great influence, if the country experienced a similar financial crisis or financial risk, so it must be more huge blow. To prevent financial crisis and financial risks from the government, banks, the public to start with. To establish a good idea of the development of the national economy, the government must pay attention to the financial risk control, the risk index must give priority to the key, and take the corresponding measures. 


\section{Conclusion}

Macroeconomic uncertainty is the important factor to influence the development of our national economy, we should timely analysis of good sources of macroeconomic uncertainty problems, and these factors influence on our national economy. In the final analysis, we still have to look at their own efforts to deal with macroeconomic uncertainty, combined with national conditions, combined with their actual economic development status, to find the right path of development of their own national economy. Of course, this is a long and arduous road, the need for our country to engage in the relevant areas of the joint research and discussion of experts, as well as the government's strong support and focus.

\section{References}

[1] Zhang Shengkun, focusing on the transformation of green - the third industrial revolution and the marine industry in 2011

[2] Binghai Zhang Xiaoyun Xin Tao Jiang "economic uncertainty and credit supply" in 20155

[3] Chen Zhao Yaxing, "the financial support strategy of environmental protection industry" in 201519

[4] Zhang $\mathrm{Na}$ Zhang Caixia, relying on the consumption of residents to upgrade the development of new services to promote economic growth in the 4 phase of 2013

[5] Ma Guangyuan. Read the new economic norm Chinese J. Business review, 2014 (6): 26

[6] Zhang Huilian, Wang Hongju. Chinese economy "new normal" (J). Banker, 2014 (6): 11-13.

[7] Zhang Zhancang, Yang Zhou Xun. Chinese economic new normal and Henan new opportunities for N. Economic viewpoint newspaper, 2014-11-06 4 on the economic development of the new normal China [J] "business story" Zhong Jingwen, 2014

[8] China economic new normal and developed countries in the "new normal" in five different $\mathrm{N}$. The Securities Journal, 2014-12-13 (B02)

[9] Xinhua news agency. The central economic work conference was held in Beijing. People's daily, 2014-12-12 (1), N (6).

[10] Ye Yu. The modern international economy and trade development trend to discuss [J]. Heilongjiang science. 2014 (10) 